Archives de sciences sociales des religions

135 | juillet - septembre 2006

Réveils du soufisme en Afrique et en Asie

\title{
Translocal networks of saints and the negotiation of religious disputes in local contexts
}

Roman Loimeier

\section{(2) OpenEdition \\ 12 Journals}

Electronic version

URL: http://journals.openedition.org/assr/3687

DOI: $10.4000 /$ assr.3687

ISSN: $1777-5825$

Publisher

Éditions de l'EHESS

Printed version

Date of publication: 1 September 2006

Number of pages: 17-32

ISBN: 2-7132-2093-9

ISSN: 0335-5985

Electronic reference

Roman Loimeier, «Translocal networks of saints and the negotiation of religious disputes in local contexts », Archives de sciences sociales des religions [Online], 135 | juillet - septembre 2006, Online since 16 October 2009, connection on 02 May 2019. URL : http://journals.openedition.org/assr/3687 ; DOI : 10.4000/assr.3687 


\section{Roman Loimeier}

\section{Translocal networks of saints and the negotiation of religious disputes in local contexts ${ }^{1}$}

\section{Introduction}

Nowadays we do not meet saints often, and when we meet them, we do usually not perceive them as such: They seem to be "out of context" in places where we do not expect them. ${ }^{2}$ Thus I met my first sûfî saint (walî), ${ }^{3}$ in an elevator at the university of Bayreuth, in 1985. Alas, at that time I didn't know that I was standing in front of such a saintly person and just assumed that I was exchanging some words of small talk with an elderly, respectful looking religious scholar from Zanzibar. His name, Sayyid 'Umar 'Abdallâh, did not mean anything to me.

Some few months later, when I had started my first research project on the development of a reform movement within the Qâdiriyya sûfî brotherhood ${ }^{4}$ in Kano, Northern Nigeria, I became better acquainted with the ways of saints and

1. I have chosen to stick here to the term "translocal", as the widely used alternative term "transnational" is too strongely linked with the concept of the national state. The notion of "translocality" may, by contrast, be applied to "pre-nation" historical contexts or contexts beyond the nation state as well (for an extensive discussion see DAvo-RundBRIEF, 2003). For inspiration and critical discussion of my paper, I would like to thank the participants of a workshop on translocal and transnational networks at the Center of Modern Oriental Studies in Berlin, in particular, Achim von Oppen, Muhammad Tâlib and Muhammad Bakari, as well as the Seminar on International Relations at Columbia University, New York, in particular, Ousmane Kane, Greg Mann, Brian Larkin and Catherine Coquery-Vidrovitch, but also, as always, Rüdiger Seesemann, Northwestern, for his constructive critique.

2. For modern appearances of saints see GILSENAN, 1973. The variegated nature of saints and holy men as well as the nature of their miracles (karamât), has led Michael Gilsenan to conclude that the "miracle/saint is one in the eyes of the believer": i.e. holyness should always be seen as a matter of interpretation (GILSENAN, 1973, p. 32).

3. The term "walî" is often translated as "friend" (i.e. of God, wali ullâh) and understood, as such, in a rather religious and/or spiritual way. Yet, the original meaning of this term was different and linked with the political concept of the "walî" as being an "ally" of God. This concept had developped, in the $8^{\text {th }}$ and $9^{\text {th }}$ centuries, in conscious opposition to the concept of the 'ulamâ and, in particular, of the fuqahâ', as being "allies" of the Ummayad and Abbasid rulers who again tried to present themselves as "khalîfat ullâh", i.e. representatives of God (on earth). I am grateful to Jamil M. Abun-Nasr for this information.

4. Understood here as a spiritual path, linked with specific methods of meditation, specific teachings, behavorial codes, and a distinct disciple-master relationship. 
holy men through my contact with the founder of this reform movement, Shaykh Nasiru Kabara, who had accepted me as a student, immerged in a peculiar quest for knowledge (talab al-'ilm), namely doing research for a Ph. D. thesis (see Loimeier, 1997). I was allowed to enter the "inner circle" of Nasiru Kabara's family and was able to learn a lot about the teachings and practices of sufism as well as the translocal connections of a sûfî brotherhood, a tarîqa, such as the Qâdiriyya.

A major event in the translocal life of the Qâdiriyya was the annual celebration of the birthday of the founder of the tarîa, the mawlid 'Abd al-Qâdir (al-Jilânî), in Kano in early 1987, that brought together a huge crowd of followers of Nasiru Kabara from all over Kano, Northern Nigeria, and Nigeria, as well as other parts of the Muslim oikumene. Thus, I was able to meet delegations from the Sudan, Libya, Mali and Niger, and was finally introduced to a big man sitting to the left of Nasiru Kabara during the different ceremonies of the mawlid. This man turned out to be the contemporary supreme leader (qutb, arab., pole) of the Qâdiriyya, in general, and the head of the spiritual centre, the zâwiya of the tarîqa in Baghdad, in particular. However, this venerable person, Shaykh Saif al-Dîn b. 'Abd al-Qâdir al-Jîlânî, as he was called, was not quite as forthcoming with me as my local friends, who had come to appreciate my presence as a student and "protégé" of Nasiru Kabara. I attributed this shyness on Shaykh Saif al-Dîn's side initially to the fact that my beard was longer than his own and that he probably assumed that I was an eminent religious scholar from Germany. Later on I found out, however, that Shaykh Saif al-Dîn's unwillingness to communicate with me was rather due to the fact that he was accompanied by an unfriendly looking representative of the Iraqi secret service.

But, these first contacts with the Qâdiriyya in Nigeria were to remain, for the time being, inconsequential as I never returned to Nigeria after having finished my Ph. D. and subsequently shifted to Senegal for my next research project (see Loimeier, 2001). In Senegal, I largely concentrated on the relationship between the state, the sûfî brotherhoods and the Muslim reformers, in particular Cheikh Touré the founder of the "Union Culturelle Musulmane" (UCM), and met some religious scholars of the Tijâniyya and the Murîdiyya, Senegal's dominant sûfî brotherhoods. The only real contact I had with the Qâdiriyya in Senegal was a trip with a qâdirî taxi-driver in St. Louis, who turned out to be the only taxi-driver in St. Louis not affiliated with either Tijâniyya or Murîdiyya, and driving with him was not a very spiritual experience. As a consequence I lost, for the time being, contact with the Qâdiriyya.

\section{Sayyid 'Umar 'Abdallâh}

Some years after my return from research in Senegal, I was lucky to get a third research project funded in 2001, this time on the development of Islamic education in Zanzibar, and this project turned out to be a return to the networks 
of the Qâdiriyya, even if it did not look as such in the beginning. Thus, I had to realize that most mosques, religious foundations, the different institutions of government controlled education, the office of the muftî and the administration of Islamic law were by and large controlled by reformist teachers and functionaries, who had mostly studied in the Sudan and Saudi Arabia. The majority of independent qur'anic schools outside the government controlled sector of education was affiliated, however, with the scholars of the Qâdiriyya and the 'Alawîyya, the latter being a network of scholars from Hadramaut in Southern Arabia who claim sharifian descent, ie. descent from the family of the Prophet. ${ }^{5}$

Scholars of the Qâdiriyya had indeed formed a major pillar of Islamic scholarship in Zanzibar in the late $19^{\text {th }}$ century, while in the $20^{\text {th }}$ century the scholars of the Qâdiriyya acquired considerable social influence due to their specialization in the fields of 'ilm al-falak (arab. astrology, astronomy), their celebration of the birthday of the Prophet, the mawlid al-nabî, their healing services (Kiswahili: uganga; arab. tibb), as well as their distinctive religious practices such as the $d h i k r$, the sûfî ritual of meditation. By the late colonial period, the activities of the Qâdiriyya in Zanzibar seem to have largely concentrated on these aspects of Islamic ritual practice, healing and divination, while most institutions of Islamic learning were dominated by scholars affiliated with the "Alawiyya. But, I soon found out that there were exceptions to the rule such as the first Zanzibarian director of the Muslim Academy, the first modern institution of Islamic higher learning in Zanzibar, as established in 1951. The name of this person was Sayyid 'Umar 'Abdallâh, and he was regarded, in the 1950s and 1960s, as one of the greatest scholars in Zanzibar, nicknamed "Mwinyi Baraka", the "Master of Blessing". And although Sayyid 'Umar "Abdallâh had died in 1988, his legacy was still very much alive in Zanzibar in 2001, in the guise of his students who had risen to eminent positions in Zanzibari society. When a local scholar, the historian and archivist Mwalimu Muhammad Idrîs Muhammad, eventually showed me a photograph of Sayyid "Umar 'Abdallâh, I had a "déjà-vu" experience: I realized that I had met this man before, namely in Bayreuth way back in 1985, in the elevator of our institute.

My surprise and "the world-is-small-feeling" got even more accentuated, when I found in the Zanzibar National Archives (ZNA) Sayyid 'Umar 'Abdallâh's personal file and subsequently learned more about his life. According to this file, Sayyid 'Umar 'Abdallâh (Al Abî Bakr b. Sâlim) was born in Zanzibar in 1918, was educated at both government and qur'ânic schools, went to Makerere college in Uganda for higher studies in the 1940s and to the School of Oriental and African Studies in London in 1951 where he studied Arabic and Islamic Law with M. Cowan and J.N.D. Anderson. After a short trip to the US in 1953, he

5. For the 'Alawî networks in East Africa see BANG, 2003. 
applied for funds for a journey to Iraq, ${ }^{6}$ but his plea was rejected by the British colonial administration in Zanzibar that was in charge of his grant. In late 1953 he applied again, this time to get funds for a pilgrimage to Mecca as well as a short stay in Hadramaut, to improve his Arabic. ${ }^{7}$ This time, the British administration agreed, as the British obviously wanted to have a credible candidate for the position of the director of the Muslim Academy. And on the way back to Zanzibar, Sayyid 'Umar 'Abdallâh visited Mecca and the Hadramaut (ZNA AB 86/47). In early 1954, he assumed the position of the director of the Muslim Academy, ${ }^{8}$ yet, left Zanzibar again in 1961 to study at Oriel College in Oxford for a BA in Islamic studies. For his thesis on Islamic philosophy, he focused on four centres of Islamic learning, namely Zanzibar, Syria, the Hadramaut and Nigeria.

As the personal file on Sayyid 'Umar 'Abdallâh in the ZNA documented his visit to Nigeria in 1961, I was quite sure that he had met, as "an ardent member of (the) Kadiriya tarîa" (Muhammad, 1992, p. 6), Shaykh Nasiru Kabara, who had already become a major scholar of the Qâdiriyya in Kano, by that period of time. When back to my study in Bayreuth, I consulted my Ph. D. thesis and found Sayyid 'Umar 'Abdallâh's name as number 118 in a list of 120 local representatives (muqaddamûn) of Nasiru Kabara. My text read: "Malam Shehu Umar, muqaddam of Nasiru Kabara in Zanzibar", and I had added, in brackets: "This claim seems to be more or less propagandistic. Shehu Umar is not only older than Nasiru Kabara, he is also a descendant of an old sharifian family" (Loimeier, 1997, p. 342). This piece of information was, as it turned out, not quite true, as I had to realize in Zanzibar, in 2001: Sayyid 'Umar 'Abdallâh had indeed become a muqaddam, a local representative of Nasiru Kabara in Zanzibar, although he did not become, like Nasiru Kabara in Nigeria, the leader of a mass movement of the Qâdiriyya. He probably did not have the chance to pursue such a career, as Zanzibar experienced, in 1964, a revolution that brought about massacres, the death of thousands and the expulsion or flight of most scholarly families. On account of his position as an independent scholar, Sayyid 'Umar 'Abdallâh was allowed to stay, however, and continued to teach in local Islamic schools until 1968, when he emigrated to the Comoros where he continued to teach in his own madrasa. In the Comoros, he also started to fight, ${ }^{9}$ however, against a specific Comorian social practice, namely the "grand marriage", the extended celebration of the marriage that was linked with rather conspicuous

6. A journey that would have enabled him to visit the tomb of 'Abd al-Qâdir al-Jîlânî.

7. In his letter of application, Sayyid 'Umar 'Abdallâh argued that such a journey would be good for his practice of Arabic, and (quote) "moreover, I must confess that to maintain in proper balance of my personality, I badly need a few weeks of intensive religious concentration after a three years stay in highly materialistic surroundings" (ZNA AB 86/47).

8. After Muhammad Muhammad ad-Dahhân, who had been the first principal from 1951 to late 1954.

9. Communication Muhammad Bakari, Nijmegen, 12.09.2004. 
features of consumption, enormous expenditure and excessive festivites. Still, he was nominated "ambassador" of the Comoros for "Islamic affairs", in 1975, when "Alî Sâlih (Soilih) took over power in the Comoros, and consented, ${ }^{10}$ in 1978, to work for the Râbitat al-'Alam al-Islâmî, the Mecca and Medina based "Muslim World League" that was known for its "fundamentalist" Wahhâbî orientations. On the ticket of the Râbita, he continued to travel widely in the Islamic world as well as the West, and visited amongst other places New York, to adress the General Assembly of the United Nations, as well as Bayreuth, where I met him in 1985 in the elevator of our institute.

\section{Translocal networks of saints I: East Africa and Baghdad in the $19^{\text {th }}$ century}

While the personal links and networks of a "saint" and scholar such as Sayyid "Umar "Abdallâh show how "translocal" in character these personal networks may be, "translocal" networks of a sûfî scholar could also be analyzed from other perspectives. These different approaches to the analysis of translocal links of a sûfî-scholar may focus, for instance, on the religious, commercial, political, social or cultural aspects of sûfî networks. In my following deliberations, I would like to concentrate on just one additional aspect of network dynamics, namely the importance of translocal links within a sûfî brotherhood for the negotiation of religious disputes in local contexts.

Translocal links in physical as well as virtual terms ${ }^{11}$ within a sûfî brotherhood may again be of paramount importance for network dynamics in several ways: The visit of Shaykh Saif al-Dîn to Kano in 1987 demonstrated, for instance, that the spiritual centre of the Qâdiriyya in Baghdad was rather keen to cultivate its bonds with such a dynamic local branch of the Qâdiriyya as the one led by Nasiru Kabara. But links with the centre of a sûfî brotherhood may also be cultivated by the local branches of a tarîa, as, for instance, in contexts of conflict over issues of leadership, or when individual, often young scholars try to introduce new ritual practices that stress the distinctive touch of their initiatives of reform. In order to defend these "innovations" that are often denounced, in the respective local discursive context, as "unislamic innovations" (arab. bida"), they establish

10. Under the influence of 'Abdallah 'Umar Natîf (b. 1939, from in 1983 the general secretary of the Râbita, see SCHULZE, 1990, p. 242ff).

11. Such links and chains of spiritual authority (silsila, pl. salâsil) within networks may be realized by travelling scholars and students, pilgrims and businessmen, but also through texts and letters, or dreams, or, in modern times, the internet; for the importance of dreams in religious networks, see the case of Shaykh 'Abd al-Muhyî from Western Java who travelled, in the early $17^{\text {th }}$ century, in a dream to Baghdad, where he visited the tomb of the founder of the Qâdiriyya sûfî brotherhood, 'Abd al-Qâdir al-Jilânî, who subsequently commanded him to establish a branch of the Qâdiriyya in Western Java. This branch of the Qâdiriyya in Western Java was later linked, by an equally imagined (or invented), yet detailed chain of spiritual authority of many saints, to Baghdad (see KraUs, 2000). 
a legitimatory link with the spiritual centre of the tariqa, in the case of the Qâdiriyya, Baghdad, and the blessing power, the baraka, of the tomb of 'Abd al-Qâdir al-Jilânî, the founder of the tarîqa. In the following, I would like to illustrate the importance of these legitimatory links for the negotiation of disputes or the propagation of claims for spiritual leadership within a sûfî brotherhood, by presenting two case studies, namely the movements of ritual reform as represented by Shaykh Uways al-Barawî in East Africa and Shaykh Nasiru Kabara in Northern Nigeria. ${ }^{12}$

Shaykh Uways b. Muhammad al-Barawî (1847-1909; for his biography, see Samatar, 1992; Brad Martin, 1976, as well as Scott Reese, 1999) was born in Brawa in Southern Somalia. His father, al-Hâjj Muhammad b. Bashîr, was a religious scholar. After having gone through the established disciplines in the education of a religious scholar, he went, upon advice of his teacher, Muhammad Tayînî al-Shashî, who had also introduced him to sûfî teachings, to Baghdad were he was properly initiated into the Qâdiriyya sûfî brotherhood by his teacher, Shaykh Mustafâ b. al-Sayyid Salman al-Jîlânî. In 1873, he went on pilgrimage and after some more years of studies, returned in 1880, via the Hijâz, Yemen and the coastal towns of the Benadir coast to Brawa, arriving in $1883 .{ }^{13} \mathrm{On}$ account of his great scholarship and his direct connections with the centre of the Qâdiriyya in Baghdad, he claimed, after his return home, a leading role in the local scholarly establishment. His claim, while rejected in Brawa (see Martin, 1976, p. 161-162 and Samatar, 1992, p. 53), found considerable recognition in other parts of East Africa, in particular Zanzibar, which became after 1884 a major centre of his activities. Shaykh Uways managed to cultivate excellent contacts with a number of Sultans of Zanzibar (in particular, Bargash, Khalîfa b. Sa'îd and Hâmid b. Thuwaynî b. Sa 'îd), and was able to transform his branch of the Qâdiriyya into a religious mass movement in the coastal areas as well as the East African hinterlands. ${ }^{14}$ Since the late 1880 s, his specific interpretation

12. New ritual practices, often connected with particular ecstatic (and thus, seemingly, "unorthodox") forms of ritual, have often been attacked by Muslim reformers or established, often old, local scholars, as "unislamic innovations" or "African polytheistic superstitions" even if they were not at all connected with African religious contexts but other discoursive or ritual traditions. The problem of diverging interpretations of specific religious practices by different parties due to different perspectives on these ritual practices has, in fact, been pointed out, some time ago, by Ioan Lewis, in an article titled "The Past and the Present in Islam: the Case of African Survivals", where Lewis stresses that "elements of belief and practice which are not officially recognised as part of (Muslim) international orthodoxy are often assumed to represent local 'survivals' from pre-Islamic times" (LewIs, 1983, p. 55), by both Muslim reformers as well as the orientalist academe, which has sometimes tended, in the past, to equalize traditions of Islam in Africa with notions of "unorthodoxy" or "heterodoxy".

13. During his journey home he visited the tomb of a recently deceased qâdirî scholar and saint, Shaykh 'Abd ar-Rahmân az-zayla'i in Qulunqul in the Ogaden area, where he received, on account of this visit to the saint's tomb, a "symbolic" (i.e. post-mortem or better, virtual) ijâza (arab. authorisation) of this highly venerated sûfî saint; see SAMATAR, 1992, p. 52.

14. He is actually said to have appointed 520 local representatives, khulafa', in East Africa. 
of the teachings of the Qâdiriyya became extremely popular, especially among converts to Islam. These teachings were connected with a number of distinctive religious practices, in particular, the "zikri ya kukohowa", a dhikr implying respiratory exercises of rhythmic inhaling and exhaling (anfâs; lit. "breath").

These new zikri practices were attacked, however, as an unislamic innovation by other senior scholars of the Qâdiriyya, in particular, Shaykh 'Abd al-'Azîz b. 'Abd al-Ghanî al-Amawî (1838-1896), who probably felt threatened in his own position as a paramount scholar of the Qâdiriyya of his time by the rapid spread of the competing zikri movement of Shaykh Uways. ${ }^{15}$ In one of his polemical poems against the "zikri ya kukohowa" of Shaykh Uways, Shaykh al-Amawî, for instance, claimed that the "zikri ya kukohowa" was rather resembling African dance and spirit possession cults such as Ngoma, Lelemama or Pepo, where women have a leading role (see al-Farsi, 1972, p. 14-15). ${ }^{16}$

Although, Shaykh al-Amawî attacked the "zikri ya kukohowa" as an innovation and as a form of mixing "African" customs with Islam, he had introduced himself, in the 1860s, another form of the zikri, namely the "zikri ya dufu", a dhikr with "dufu" (bandiri) drums, that had also been attacked by the established scholars of that time, as an "unislamic innovation". ${ }^{17}$ Yet, while the Amawî branch of the Qâdiriyya depicted now, in the 1890s, the "zikri ya kukohowa" of Shaykh Uways as an "unislamic innovation", the "zikri ya kukohowa" was in fact, nothing new at all for Shaykh Uways who had witnessed this form of the dhikr when he was studying in Baghdad where the "zikri ya kukohowa" was part of an old qâdirî tradition. The attacks on the "zikri ya kukohowa" as

15. This rapid spread of the zikri movement was not confined to the Muslim populations of Zanzibar and the East African coast but seems to have been a major force in the conversion of numerous non-Muslims to Islam in the East African hinterlands since the late $19^{\text {th }}$ century, as well. Both Jonathan Glassman and August Nimtz, in fact, correlate the movement of conversion to Islam in mainland Tanzania since the late $19^{\text {th }}$ century with the activities of Qâdirî dâ $\hat{\text { c }}$ s and the ritual attraction of the $d h i k r$ (see Glassman, 1995, p. 140 and NimTZ, 1980, p. 66). The growing strength of the Uways branch of the Qâdiriyya that propagated these $d h i k r$ rituals explains also the growing influence of Shaykh Uways at the court of the Sultans of Zanzibar and the fact that Shaykh Uways was able to eclipse the influence of the established Amawî branch of the Qâdiriyya, which had been favoured by the Sultans of Zanzibar, before (see POUWELS, 1987, p. 143).

16. The respective part of the poem was (as quoted in AL-FARSI, 1972, p. 14-15): "Mashekhe mnaosoma, na vitabu kufunuwa; dhikiri yenu ni ngoma, kadiri itavyokuwa; hiyo ima lelemama, au pepo kimamvuwa; wapi ilikozuliwa, ibada ya kukohowa?" (Oh you scholars, read and discover your (own) books; your dhikr is nothing but ngoma, think! why is it like that? your dhikr might even be a kind of lelemama or pepo; where was this worship of coughing invented/born?).

17. Shaykh al-Amawî defended the dhikr ya dufu in a treatise titled "tawdhîh al-mubhamât fî hukm âlat al-malâhî wa-jawabâtiha wa-fî l-tatimmât li-l-shaykhain al-ajillain al-qamarain ash-shâfi'ain al-qâdirain as-sumâliyyain al-barawiyyain ash-shaykh 'Abd al-'Azîz al-Amawî wal-shaykh al-qâdî Muhyî ad-Dîn b. "Abdallâh al-Qahtânî" ("explanation of the ambiguities with respect to the regime concerning (the use of) 'beautiful' instruments", see ALA III, forthcoming). 
an "unislamic innovation" must be seen, thus, as a function of local religious disputes that activated well known strategies of legitimization and delegitimization (see also Loimeier, 2003). ${ }^{18}$

The critique of specific forms of sûfî teachings and rituals is, in fact, often connected with dialectics of competition amongst religious scholars over questions of religious authority in rather local contexts of dispute, even if the discursive elements that are activated for the legitimization of specific religious positions are quoted from greater, translocal, and perhaps even universal discursive traditions or "frames of reference" (see Asad, 1986). These discursive traditions and strategies of argumentation have residual character and may, thus, be activated in comparable constellations of dispute, at any time should need arise. ${ }^{19}$

In the 1940s, Shaykh 'Abdallâh Sâlih al-Farsî (1912-1982), a major representative of a more recent Muslim reformist movement in East Africa, for instance, used al-Amawî's polemics against the zikri ya kukohowa of Shaykh Uways, in his own struggle against the zikri ya kukohowa practices of Shaykh Mahmûd b. Kombo from Makunduchi/Zanzibar (d. 1968), by quoting ${ }^{20}$ the polemical poem Shaykh al-Amawî had composed to attack the zikri ya kukohowa practices of Shaykh Uways in the 1890s. Shaykh 'Abdallâh Sâlih al-Farsî could point out, thus, in a very scholarly and clever way, to the Qâdiris of his days, that "even" well known and respected qâdirî scholars of "those days", such as Shaykh al-Amawî had criticized these ritual excesses (al-Farsî, 1944/1972, p. 14-15). In his polemics against the zikri ya kukohowa, Shaykh 'Abdallâh Sâlih al-Farsî never mentioned, however, that Shaykh al-Amawî had also written, in the 1860s, a treatise in defence of the zikri ya $d u f u$, although this practice could as easily be attacked as a bid' $a$ as the practice of the zikri ya kukohowa.

Although Shaykh 'Abdallâh Sâlih' al-Farsî's reference to al-Amawî̀s poem was, thus, totally out of its temporal context, it was set absolutely within a context of similar patterns of confrontation, and in each case of conflict, legitimatory links were cultivated: to Bagdad, in Shaykh Uways' case against Shaykh al-Amawî in the 1890s; to an earlier tradition of Islamic learning that was represented as being "more authentic Qâdirî" than contemporary practices, in Shaykh 'Abdallâh Sâlih al-Farsî's case against Mahmûd b. Kombo, in the 1940s. The disputes between these religious scholars clearly show, that interpretation and

18. Shaykh Uways seems to have written, in fact, numerous poems and polemic/apologetic texts in both Arabic and Somaal in defence of his teachings, see: SAmatar, 1992, p. 53 and MARTIN, 1976, p. 161.

19. This also shows, as John Voll has tried to demonstrate, that "local traditions" of Islam may represent "parochialisations" of former "universal" traditions of reform, that have been eclipsed by more recent traditions of reform that might, sooner or later, also turn into "local survivals" of reform.

20. In his famous text on the history of East African shâfi'î scholars, "Baadha ya wanavyuoni wa kishafi wa mashariki ya Afrika”, published 1944 and reprinted 1972. 
presentation of a specific ritual in the respective texts and discourses of a specific period of time, as "orthodox" or "unorthodox", as "Islamic" or "un-Islamic", as "African" or "Arab" may not only be rather deceptive, as being based on legitimatory considerations, but should also be seen to be set within contexts of dispute and the negotiation of claims for leadership and hegemony of definition (Deutungshegemonie) with respect to ritual, religious or political issues. As a consequence, the interpretation of the issues at stake as well as the legitimatory references and links may change any time, if the context changes. At the same time, patterns of legitimization and delegitimization seem to persist as stubbornly as a number of seemingly "unislamic innovations"; ${ }^{21}$ strategies of legitimization, thus, usually imply a legitimatory reference to a major centre of Islamic learning, preferably outside Africa, while strategies of delegitimization often tend to denounce specific religious practices as "African survivals". ${ }^{22}$

\section{Translocal networks of saints II: Northern Nigeria and Baghdad in the $20^{\text {th }}$ century}

A second case in which a local scholar activated a link with Baghdad in order to establish, bless and legitimize a local movement of ritual reform was Nasiru Kabara of Kano in Northern Nigeria (1925-1996, for his biography see Loimeier, 1997). He went through the normal career of a religious scholar and studied the Qur'ân, tafsîr (exegesis of the Qur'ân), figh (Islamic jurisprudence), tasawwuf (mysticism), tawhid (doctrinal theology), and 'ilm al-falak, and soon proved that he was an extraordinary student. In 1937, he wrote a letter to the khalifa of the Sammâniyya in Mecca, Shaykh Abû al-Hassan as-Sammânî, delivered by a hâjj (arab. pilgrim) from Kano, namely Wali Sulaiman, in Nasiru Kabara's name. In his letter, Nasiru Kabara asked to be accepted as a muqaddam of Shaykh Abû al-Hassan as-Sammânî in Kano, and although Shaykh Abû al-Hassan was astonished that this request came from a twelve year old boy, he accepted his

21. When I visited the zâwiya of Shaykh Mahmûd b. Kombo in summer 2003 and summer 2004 and met his successor, Shaykh Yusuf b. Sulaimân, I could witness that this zâwiya of the Qâdiriyya was not only still very much alive and active, but had also been expanded by a new school building. Also, the practice of the "zikri ya kukohowa" was still very popular: each week, delegations of the different zawâya of the Qâdiriyya in Zanzibar visited each other, crisscrossing the island with trucks full of enthousiastic disciples on the way to a "zikri" in either Makunduchi, Zanzibar-Town, Nungwi or Donge. The most stubborn supporters of the "zikri", however, seem to be the followers of the Qâdiriyya of Tumbatu island (communication Amina Ameir, 3.9.2004).

22. Assumptions of "African" survivals and ritualistic influences in "orthodox Islamic contexts" may be found in even in the most recent literature on Islamic societies in Africa, in particular, when we encounter the concept of a specific "African Islam" (see, for instance, Cruise O'Brien, Coulon, 1988 and Westerlund, 1997, introduction; for a discussion of the term see LOIMEIER, 1997, p. 59-72 and SEESEMANN, 2002), and show that we should be extremely careful when confronted with constructions such as "African Islam" or "African Traditional Religion" (ATR), for that matter, as these terms often point to "orientalist" essentializations. 
wish. The nomination as muqaddam of the Sammâniyya was to be, however, only the starting point for the collection of a long series of salâsil (arab. chains, i.e. of spiritual affiliation) from different branches of the Qâdiriyya by Nasiru Kabara. His intention in the collection of all these salâsil was, in fact, to advance his claims for spiritual leadership in Kano by establishing as many links as possible with other chains of authority of the Qâdiriyya. ${ }^{23}$ Through his salâsil, Nasiru Kabara indeed became a focus of attention and attraction for other members of the Qâdiriyya who were keen to renew their own spiritual affiliations through him and to acquire, thus, shorter spiritual connections with the respective centers of the tarîqa.

In a context of competition with other families of the Qâdiriyya in Kano, Nasiru Kabara finally saw the need to establish a direct link to the very center of the tarîa in Baghdad, to eclipse these rivalling branches of the Qâdiriyya. In 1953, at the age of 28, he travelled to Baghdad, met the supreme leader of the Qâdiriyya and visited the tomb of 'Abd al-Qâdir al-Jilânî. The fact that Nasiru Kabara had been able to meet the supreme leader of the tariqa and that he had visited the tomb of 'Abd al-Qâdir al-Jilânî, were of tremendous importance, as Nasiru Kabara was now the undisputed holder of the shortest silsila-link in Nigeria to the center of the Qâdiriyya in Baghdad. At the same time, Baghdad was able to establish a direct link with Kano and to by-pass other subcentres of the tarîqa that had so far ignored Baghdad's claims to spiritual supremacy. The importance of the Kano-Baghdad link not only for Kano but also for Baghdad was shown by the fact that the present supreme leader of the Qâdiriyya, Shaykh Saif ad-Dîn, has visited Northern Nigeria twice to meet his local muqaddam, who has turned out, in the 1970s, to be the leader of the most successful branch of the Qâdiriyya in the whole of West Africa (and perhaps even Africa). Nasiru Kabara's movement was, finally, also acknowledged by the Sultan of Sokoto, in 1978, when he recognized Nasiru Kabara as the supreme leader of the Qâdiriyya in Nigeria, thereby renouncing his own claim on supremacy that went back to Usman dan Fodio, and by handing over to Nasiru Kabara the "sword of the army of Usman dan Fodio". This symbolic act has to be seen, however, in the context of the struggle of both the Sultan of Sokoto and the Qâdiriyya against the radical reformist movement of the 'Yan Izala (i.e. the "Jamâ'at Izâlat alBid'a wa-Iqâmat as-Sunna”, see Loimeier, 1997, p. 57).

Yet, the affiliation with Baghdad not only brought about Nasiru Kabara's breakthrough as the paramount scholar of the Qâdiriyya in Nigeria, but was also and again connected with the introduction of a number of distinctive ritual practices, namely the bandiri-dhikr, the anfâs-dhikr, as well as a procession, a mawkib, in the streets of Kano to the tombs of the local saints in the context

23. Such as the Sammâniyya in Mecca, the Sammâniyya in the Sudan, the Salâmiyya in Kano, the Kunta branch of the Qâdiriyya in Sokoto as well as the zâwiya of the Qâdiriyya in Shinqît/Mauritania. 
of the annual celebration of the birthday, the mawlid 'Abd al-Qâdir. These ritual innovations were defended by Nasiru Kabara against local criticism in a number of treatises (such as "tanfîs al-jullâs fî dh-dhikr bi-l-bandîr wa-l-anfâs", ${ }^{24}$ "khulâsat at-tahrîr fi dh-dhikr bi-l-anfâs wa-l-bandîr", ${ }^{25}$ or "mawkib al-qâdiriyya fî shawâri' al-kanawiyya" ${ }^{26}$ ) as major features of the "original and authentic", ie. Baghdadcentric Qâdiriyya (see Loimeier, 1997, p. 62ff). The new forms of $d h i k r$ as well as the annual procession turned out, in fact, as in the case of Shaykh 'Uways in East Africa, to be extremely popular and were a major reason for the successful transformation of the Qâdiriyya-Nâsiriyya into a religious mass movement, first in Kano, then the whole of Northern Nigeria. As a consequence, Nasiru Kabara was never prepared to compromise with his opponents, and to abandon these practices. The bandiri and anfâs-dhikr as well as the celebrations of the mawlid 'Abd al-Qâdir have remained, thus, distinctive features of the Qâdiriyya-Nâsiriyya until today and are defended by the successor of Nasiru Kabara, Shaykh Qarîb Allâh Muhammad Nâsir Kabara. ${ }^{27}$

\section{Conclusion}

The examples of Nasiru Kabara and Shaykh Uways show that translocal links with the spiritual centre of the tariqa, such as Baghdad in the case of the Qâdiriyya, may be cultivated, for legitimatory reasons, for instance, by scholars advocating ritual reform, as well as by scholars claiming spiritual leadership within a family, a branch or a regional network of a tarîqa. The examples of Nasiru Kabara and Shaykh Uways, in addition, show that local frame conditions and contexts are of paramount importance for the development of religious movements, in particular when we look at the ways in which specific elements of a translocal tradition are translated into local contexts. It seems as if translocal traditions that usually claim universal hegemony of definition (Deutungshegemonie) may acquire social, political and religious relevance (Wirkmächtigkeit) and acceptance in the local context only, when they are explicitly "quoted" and, subsequently translated into a specific local context. This is certainly true for Nasiru Kabara and Shaykh Uways and their respective efforts to legitimize initiatives of ritual reform by establishing legitimatory links with Baghdad. Only through their efforts, a translocal tradition, as represented by Baghdad, came to be quoted in the respective local setting.

There is, however, an important difference between Nasiru Kabara's and Shaykh Uways's movements of ritual reform within the Qâdiriyya, and Sayyid

24. i.e., the refreshing of the participants in the bandiri and anfâs-dhikr.

25. i.e., the quintessence of liberation through the bandiri and anfâs-dhikr.

26. i.e., the procession of the Qâdiriyya in the streets of Kano.

27. Shaykh Qarîb Allâh Muhammad Nâsir Kabara was born in 1960, and took over the leadership of the Qâdiriyya-Nâsiriyya in 1996; for the recent development of the Qâdiriyya see BARI, 1997. His booklet also contains a list of the miracles of Shaykh Nasiru Kabara. 
'Umar 'Abdallâh: While links with Baghdad were instrumental to legitimize, in Shaykh Uways' and Nasiru Kabara's cases, the introduction of distinct rituals into a specific local context and to propagate a local movement of reform within the Qâdiriyya, Sayyid 'Umar 'Abdallâh never established such a movement of reform, and never established a legitimatory link with Baghdad: his efforts to visit Baghdad in 1953 had, in fact been futile, as we have seen above. Rather, he fought in the Comoros his own struggle against local custom and moved beyond the world of the Qâdiriyya, by cultivating different legitimatory links with the Muslim World League in Mecca and Medina, the spiritual centres of Wahhâbî Islam that subsequently supported his struggle against "unislamic innovations" on a much larger scale by financing, for instance, Sayyid "Umar 'Abdallâh's journeys and missions in the Islamic oikumene.

Universal ideologies, religions or movements of reform are, however, not intrinsically powerful. They achieve, as I have shown above, translocal or even universal relevance only when translated by many translators, into many different local contexts. Moreover, movements of reform that claim translocal or even universal hegemony of definition, and that consequently fight against allegedly "local" (African) aspects of religion, do not necessarily contribute to an increasing acceptance of some sort of "universal orthodox model" of "Islam", but rather contribute to the further expansion of the cosmos of local interpretations of Islam. Movements of reform, in fact, tend to enlarge, in manifold processes of negotiation, the spectrum of possibilities of realization of "religion". In this scenario of religious dynamics, seemingly "weak" local traditions often prevail against seemingly "strong" or "universal" traditions, as local traditions, even if not documented in texts, are rooted in specific and unique local contexts and often provide, thus, familiar frameworks for the organization of everyday life. Movements of reform that attack specific "local" concepts of religion and ritual should, consequently, not be seen automatically as "juggernauts" of reform, that blaze their way through seemingly obsolete local ("African”) customs, but rather be perceived as a "new offer" on the "market of possibilities" that acquire local relevance only if these movements of reform, as represented by their respective "translators", know how to address local needs and preoccupations (for this debate see Fisher, 1973 and 1985).

Religious dynamics have to be seen in the end, at least with respect to the Muslim societies of Africa, as an intricate web of forces that constantly interface and change according to local context as well as time. The frameworks of agency of sûfî-saints and scholars may acquire astonishing features in these local and translocal settings. The often surprising twists in the local and translocal development of religious movements may provide us, however, with an opportunity to meet, from time to time, a saint in strange contexts, such as an elevator at the university of Bayreuth.

Roman LOIMEIER Centre of Modern Oriental Studies - Berlin 


\section{Bibliography}

'AbDallah Sayyid 'Umar, 1963, Some Aspects of the Concept of Felicity in Medieval Islamic Philosophy, B.A. Thesis, Oxford, Oriel College.

AsAD Talal, 1986, "The Idea of an Anthropology of Islam”, Occasional Papers of the Center for Contemporary Arab Studies, Georgetown, University of Washington.

BAKARI Muhammad, 2002, "A Muslim Humanist: The Thought of Sayyid Omar Abdallah (1918-1987) and its social impact on East Africa and the Grand Comoros”, Istanbul, Unpublished Paper.

BANG Anne, 2003, Sûfîs and Scholars of the Sea. The Sûfî and Family Networks of Ahmad ibn Sumays and the tarîa 'Alawiyya in East Africa, c. 1860-1925, London, Routledge \& Curzon.

BARI Sarki Bello, 1997, Taurarin Kadiriyya, Kano, Gwadabe Zakari Kurawa.

Cruise O'Brien Donald B., Coulon Christian, eds., 1988, Charisma and Brotherhood in African Islam, Oxford, Oxford University Press (Oxford Studies in African Affairs).

Davo-Rundbrief, 2003, "Translocality in the modern history of the Middle East, Asia and Africa", Presentation of the current research programme at the Zentrum Moderner Orient, Berlin/Mainz.

AL-FARSI Shaykh 'Abdallâh Sâlih, 1944/1972, Baadhi ya wanavyuoni wa kishafi wa mashariki ya afrika, Mombasa.

FISHER Humphrey, 1973, "Conversion reconsidered: some historical aspects of religious conversion in Black Africa”, Africa, 43, p. 27-40.

FISHER Humphrey, 1985, "The juggernaut's apologia: conversion to Islam in black Africa", Africa, 55, p. 2.

GiLSENAn Michael, 1973, Saint and Sûfî in Modern Egypt - an Essay in the Sociology of Religion, Oxford, Oxford University Press.

Glassman Jonathan, 1995, Feasts and Riots. Revelry, Rebellion and Popular Consciousness on the Swahili Coast, 1856-1888, Portsmouth, Heinemann.

Horton Robin, 1971, “African conversion”, Africa, 41, 2, p. 85-108.

Kabara Nasiru, n.d., Tanfîs al-jullâs fî dh-dhikr bi-l-bandîr wa-l-anfâs, Kano.

KABARA Nasiru, n.d., Khulâsat at-takbrîr fi dh-dhikr bi-l-anfâs wa-l-bandîr, Kano.

KABARA Nasiru, n.d., Mawkib al-qâdiriyya fî shawâri' al-kanawiyya, Kano.

Kane Ousmane, 2003, Muslim Modernity in Postcolonial Nigeria. A Study of the Society for the Removal of Innovation and Reinstatement of Tradition, Leiden, Brill.

KRAUS Werner, 2000, “Imaginierte und reale Netzwerke in Indonesien”, in Roman LOIMEIER, ed., Die islamische Welt als Netzwerk. Möglichkeiten und Grenzen des Netzwerkansatzes im islamischen Kontext, Hamburg, LIT, p. 289-310.

LewIs Ioan M., 1983, "The Past and the Present in Islam: the case of African 'survivals'”, Temenos, 19, p. 55-67.

Loimeier Roman, 1997, Islamic Reform and Political Change in Northern Nigeria, Evanston, Northwestern University Press.

LOIMEIER Roman, ed., 2000, Die islamische Welt als Netzwerk. Möglichkeiten und Grenzen des Netzwerkansatzes im islamischen Kontext, Hamburg, LIT.

LOIMEIER Roman, 2001, Säkularer Staat und islamische Gesellschaft. Die Beziehungen zwischen Staat, Sufi-Bruderschaften und islamischer Reformbewegung in Senegal im 20. Jahrbundert, Hamburg, LIT. 
30 - ArChives de SCIENCES SOCIALES DES RELIGIONS

LOIMEIER Roman, 2003, "Where was this Worship of Coughing invented? Processes of Transculturation from an Islamic Perspective", in A. JONES, ed., Transculturation: Mission and Modernity, Leipzig, University of Leipzig (Papers on Africa/Mission Archives Nr. 22, p. 33-42).

Martin B.G., 1969, "Muslim Politics and Resistance to Colonial Rule: Shaykh Uways b. Muhammad al-Barawi and the Qâdiriyya Brotherhood in East Africa", Journal of African History, X, 3, p. 471-486.

Martin B.G., 1976, Muslim Brotherhoods in $19^{\text {th }}$ century Africa, Cambridge, Cambridge University Press.

Muhammad Yusuf Abdulrahman, 1992, "Brief Memoirs of the Late al-Marhum al Seyyid Omar bin Abdulla Ali-Sheikh”, Zanzibar, unpublished paper.

Nimtz August H., 1980, Islam and Politics in East Africa, Minneapolis, University of Minnesota Press.

O'FAHEY Sean, ed., in print, East Africa to the $19^{\text {th }}$ century, Arabic Literature of Africa, vol. III., Leiden, Brill.

Pouwels Randall L., 1987, Horn and Crescent. Cultural Change and Traditional Islam on the East African Coast, 800-1900, Cambridge, Cambridge University Press.

RedFIELD Robert, 1956, Peasant Society and Culture, Chicago, University of Chicago Press (repr. edition 1989).

SAMATAR Said S., 1992, "Sheikh Uways Muhammad of Baraawe, 1847-1909: Mystic and Reformer in East Africa”, in Said S. SAmatar, ed., In the Shadow of Conquest. Islam in Colonial Northeast Africa, Trenton, The Red Sea Press, p. 48-74.

SCHULZE Reinhard, 1990, Islamischer Internationalismus im 20. Jahrhundert, Leiden, Brill.

SEeSEMAnN Rüdiger, 2002, "Ein Dialog der Taubstimmen". Französische vs. britische Wahrnehmungen des Islam im spätkolonialen Westafrika, Afrika Spectrum, 37, 2, p. 109-140.

StewART Charles C., 1973, Islam and Social Order in Mauritania, Oxford, Clarendon Press.

Westerlund David, Evers-Rosander Eva, eds., 1997, African Islam and Islam in Africa. Encounters between Sûfîs and Islamists, London, Hurst.

ZIDDY Issa, 2001, Athar minhaj at-tarbiya al-islâmiyya 'alâ Tullâb al-marhala aththânawiyya fî zinjibâr fî l-fatra 1964-1999, Ph. D. Thesis. Khartoum, Jâmi‘at Ifrîqiyya al-âlamiyya.

Zanzibar National Archives:

Personal File Sayyid 'Umar 'Abdallâh, ZNA AB 86/47.

Muslim Academy, ZNA AD 23/17, minute 54. 


\section{Résumé}

Les exemples de Shaykh Nasiru Kabar et Shaykh Uways montrent que des liens trans-locaux avec le centre spirituel de la tarîqa, tels que Bagdad dans le cas de la Qâdiriyya, peuvent être cultivés pour différentes raisons. Cependant, les exemples de Nasiru Kabara et Shaykh Uways montrent également que les conditions et les contextes locaux sont très importants dans le développement de mouvements religieux, en particulier lorsque l'on considère la façon dont des éléments spécifiques d'une tradition trans-locale ou même universelle sont traduits dans les réalités locales. Il semble que les traditions trans-locales ou universelles ne peuvent être acceptées que si elles sont "citées" et, ensuite "traduites» dans un contexte local spécifique. Cela est certainement vrai pour Nasiru Kabara et Shaykh Uways et leurs efforts respectifs visant à faire accepter des initiatives de réformes rituelles en établissant des liens légitimateurs avec Bagdad. C'est seulement à travers leurs efforts qu'une tradition trans-locale, représentée par Bagdad, a pu être citée dans les contextes locaux respectifs.

Mots-clés : Soufisme, Afrique orientale, Tanzanie, Zanzibar.

\section{Abstract}

The examples of Shaykh Nasiru Kabara and Shaykh 'Uways show that translocal links with the spiritual centre of the tarîqa, such as Baghdad in the case of the Qâdiriyya, may be cultivated for many reasons. The examples of Nasiru Kabara and Shaykh 'Uways, however, also show that local frame conditions and contexts are of major importance for the development of religious movements, in particular, when we look at the ways in which specific elements of a translocal or even universal tradition are translated into local contexts. It seems as if translocal or universal traditions may win acceptance in the local context only, when they are explicitely "quoted" and, subsequently, translated into a specific local context. This is certainly true for Nasiru Kabara and Shaykh 'Uways and their respective efforts to legitimize initiatives of ritual reform by establishing legitimatory links with Baghdad. Only through their efforts, a translocal tradition, as represented by Baghdad, came to be quoted in the respective local setting.

Key words: Sufism, East Africa, Tanzania, Zanzibar.

\section{Resumen}

Los ejemplos de Shaykh Nasiru Kabar y Shaykh Uways muestran que los lazos translocales con el centro espiritual de la tarîqa, como Bagdad en el caso de la Qâdiriyya, pueden ser cultivados por diferentes razones. Los ejemplos de Nasiru Kabara y Shaykh Uways muestran que las condiciones y los contextos locales son muy importantes en el desarrollo de movimientos religiosos, en particular cuando se considera la manera en que elementos específicos de una tradición trans-local o aún universal son traducidos en las realidades locales. Pareciera que las tradiciones trans-locales o universales sólo pueden ser aceptadas si son «citadas " y luego " traducidas » en un 
32 - ArChives de SCIENCES SOCIALES DES RELIGIONS

contexto local específico. Esto es ciertamente verdadero para Nasiru Kabara y Shaykh Uways y sus esfuerzos respectivos por hacer aceptar las iniciativas de reformas rituales estableciendo lazos legitimadores con Bagdad. Es sólo a través de sus esfuerzos que una tradición trans-local, representada por Bagdad, ha podido ser citada en los contextos locales respectivos.

Palabras claves: Sufismo, Africa orientale, Tanzania, Zanzíbar. 